\title{
Job Responsibilities and Job Satisfaction at the University of California Libraries
}

\section{Patricia A. Kreitz and Annegret Ogden}

The authors compare the roles and responsibilities of academic librarians and support staff at the nine-campus library system of the University of California. By surveying the frequency with which certain tasks were performed, areas of overlap between professionals and paraprofessionals were identified. Discrepancies in satisfaction with specific job attributes are examined. A wide gap in satisfaction levels between the two groups was found, particularly in the areas of promotion, job development, and influence. While calling for equity in compensation for library assistants, the paper identifies the responsibilities of professional librarians in setting realistic expectations for library staff.

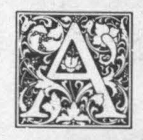

ccording to a 1988 Personnel Journal survey of 100 corporate personnel officers "job satisfaction is ranked over job security by a 2 -to- 1 margin as the number one worker concern today." ${ }^{\prime 1}$ Margaret Magnus, editor/associate publisher of Personnel Journal, speculated that this change in worker concern may be driven by "the appearance of a new class of knowledge workers who are being paid for what they know, not just what they do.."2 These knowledge workers expect more from their jobs. This change may require employers to develop new concepts of leadership, compensation, and managerial control.

If job satisfaction is important for American workers in the profit sector, it may be even more significant in knowledge industries such as academic libraries. One of the traditional assumptions about careers in an academic setting is that such work offers a high level of satisfaction. Librarians and library assistants expect their jobs to satisfy not only their financial needs but also their intellectual and psychological needs. Moreover, they expect to receive both monetary and nonmonetary compensation commensurate with their education. But are these expectations realistic in the present employment structure of university libraries? And, in addition, do the rewards match the responsibilities and the qualifications?

In Understanding Job Satisfaction, Gruneberg suggests that occupations that depend heavily on cooperation among fellow workers and whose product is a service function directed toward a nonpaying public (in contrast to a salesoriented or manufacturing function) would be adversely affected by a high level of dissatisfaction among employees. ${ }^{3}$ Service industries operating in the nonprofit sector are particularly dependent on intangible rewards to influence job performance since they traditionally have lower wages and benefits and since relatively low pressure is put on employees through administrative supervision. ${ }^{4}$ As nonprofit service industries fill with "knowledge

Patricia A. Kreitz is Manager of Library Services at the Superconducting Super Collider Laboratory Library, 2550 Beckleymeade Avenue, Dallas, Texas 75237. At the time of authoring the article, Kreitz was Head of General Reference for the University of California at Berkeley. Annegret Ogden is at the Bancroft Library, the University of California at Berkeley, 94720. 
workers," libraries should be affected by the close connection perceived between a high level of job satisfaction and a high quality of library service. There are, however, some interesting indications in the literature that, although a high level of satisfaction exists in libraries, it is not experienced equally by all library workers.

In theory, but as our study will show not so much in practice, academic librarians are in charge of library policies and operations. In accordance with their special background and higher education (a master's degree in library science is a prerequisite) they serve as consultants to faculty and students and perform those tasks that require familiarity with academic subject matters and bibliographic skills. They administer, analyze, and organize the services. To a large extent, performing these services devolves to the library assistants who function in a separate employment structure, designed to relieve librarians of the routine aspects of their work.

In his article entitled "Continuity or Discontinuity-a Persistent Personnel Issue in Academic Librarianship," Allen Veaner asserts that library assistants are highly dissatisfied with their job duties and rewards because librarians have not been able to maintain a clear distinction in job duties and responsibilities between the professional and the nonprofessional levels. ${ }^{5}$ In the University of California system, library assistant is a specific classification that denotes library staff who are not hired into positions requiring an M.L.S. but who do support-level library tasks. Synonyms for these positions are: library clerks, library technical assistants, and paraprofessionals. Veaner argues that there is a "widespread perception that two categories of employees (librarians and library assistants) are performing widely overlapping functions, seemingly at the same level, but in different employee series with different pay scales and different prerequisites. ${ }^{\prime \prime}$ This blurring of responsibilities - and the dissatisfaction it engenders-is not limited to American libraries. Norman J. Russell, surveying nonprofessional staff in a selection of public and academic libraries in England and Northern Ireland, discovered a "deep re- sentment" by paraprofessionals of the professional staff's treatment of them. ${ }^{7}$ These paraprofessionals also reported a considerable overlap in the duties of professional and paraprofessional staff, an overlap that they did not feel was adequately compensated in the salaries paid to paraprofessional staff. Russell concludes that "It is difficult to escape the conclusion that relationships between professional and nonprofessional are not what they should be. ${ }^{\prime \prime}$

Since librarians and library assistants interact with each other on a daily-often hourly-basis, common sense suggests that the dissatisfaction and/or ambiguity experienced would have an effect on the relationship between the two groups and, to some extent, on the quality of service they provide library users. Are Veaner's assertions accurate that the blurring of roles is widespread and that this causes a high level of dissatisfaction for library support staff? If so, is this condition caused by a real or a perceived overlap of the work each group performs? Library folklore, and the ad hoc experiences of these two researchers, suggest that Veaner's assertions are correct. However, we found no comprehensive study that tested his assumptions and decided to explore this issue within the context of the University of California libraries by comparing the job satisfaction experienced by academic librarians and paraprofessional library assistants with their self-reported tasks and responsibilities. The University of California system of libraries offers an excellent environment for a job satisfaction study comparing professional and paraprofessional workers. In 1983 when this study was conducted, there were 599 librarians and 1,573 library assistants working in over sixty libraries at nine campuses across the state of California.

A master's in library science is a prerequisite for employment in the librarian series that follows the faculty model of three ranks: assistant librarian, associate librarian, and librarian, with a provision that career status (a variant of tenure) be achieved within six years after the initial employment or the individual is not retained. Movement through the three 
ranks is by means of steps within rank and then promotions from rank to rank. Librarians lack detailed job descriptions; instead their performance and thus their movement through steps and ranks is based on an assessment of their overall achievement. The career path of librarians at the higher ranks is to a large degree independent of their primary job responsibilities because as they advance in rank, they are expected to spend an increasing percentage of time on professional, scholarly, or university service and/or on research.

In contrast to librarians, library assistants are judged on their performance in specific jobs that have formal, detailed job descriptions. At the time of our study, there were four ranks of library assistants within the U.C. system. A particular job is classified at level one, two, three, or four based upon the duties and responsibilities involved. An individual is hired into a particular job and can receive recommended merit increases that advance the employee through a fixed number of steps, usually five. However, once a library assistant has reached the top of the pay scale for that level, no more advancement is possible unless individuals are hired into a different job or have a significant number of higher-level duties reassigned to them. While merit increases within a level are based on an individual's performance, movement between steps within the library assistant series-in contrast to the librarian series-is dependent upon the formal structure and content of the job. Top-ranking assistants generally supervise the work of other assistants and manage entire work units or departments, but always within the restraints of their supportive, functional relationship to the academic librarians who set the guidelines and evaluate their work.

Through our experience as librarians in technical and public service, we became aware of a gradual shifting in roles that seems to be undermining the traditional distinction between professional and support staff. Pressures caused by changes in technology and by budget restrictions seem to be resulting in deprofessionalization of staff. Librarians who felt overbur- dened by clerical duties saw themselves prevented from participating in activities that encouraged professional growth. Library assistants who took on additional responsibilities felt the lack of adequate compensation and recognition. In order to test whether these perceptions of deprofessionalization and discontent were true, we decided to study the job satisfaction and job duties of these two groups to determine whether there was significant blurring between professional and paraprofessional roles.

\section{LITERATURE REVIEW}

Some recent job satisfaction studies have pointed out how difficult it is to isolate contentment in the work place from an individual's general state of mental health. ${ }^{9}$ The question of what frame of reference a person uses in assessing a job, the work environment, and work relationships is problematic because of a complex interaction of childhood predispositions, attitudes about work, and changing worker needs and perceptions over time. However, a counterpoint to this individualistic approach to job satisfaction is the argument that all people have certain needs, even if they prioritize those needs differently at different times, and that problems in an organization or in job structure within a work force can be identified through the sheer weight of consistent responses that seem to violate or meet significant human needs. ${ }^{10}$

The vast amount of published literature on job satisfaction testifies to the perceived importance satisfaction has in the work place. A number of those studies have examined job satisfaction experienced by library employees. However, few studies have specifically compared the job satisfaction of professional and paraprofessional staff within libraries. Beverly P. Lynch and Jo Ann Verdin studied full-time staff in three academic libraries. ${ }^{11}$ Staff were in departments performing either book selection, acquisitions, cataloging, circulation, or reference. The nature of the functions chosen would limit the majority of respondents to either the professional or paraprofessional categories. They were able to 
verify only one of their seven hypotheses tested, that there is no significant difference between men and women library employees' job satisfaction. Our findings matched theirs. Their further discovery that librarians reported higher levels of satisfaction than paraprofessionals again matched our findings and supports Veaner's assertion of a division in level of job satisfaction along structural lines. Other studies, which focused solely on professional job satisfaction, support Lynch and Verdin's finding that professional staff are, on the whole, relatively happy with their work and find it intrinsically satisfying. ${ }^{12}$ William J. Vaughn and J.D. Dunn compared job satisfaction among six university libraries and, within one library, by six departmental subgroupings. ${ }^{13}$ While data was collected on the respondents' occupational levels, the study's primary focus was on comparing organizational and structural differences; thus, no data on the relationship of satisfaction to occupational level was reported.

We became aware of a gradual shifting in roles that seems to be undermining the traditional distinction between professional and support staff.

Two studies have reported library professional staff as having a lower satisfaction rating than other library workers. Lawrence D. Prybil investigated whether job satisfaction could be correlated to performance or occupational level for three groups within one academic library: librarians, all clerical and nonprofessional staff, and maintenance/custodial workers. ${ }^{14}$ Comparison with our study is not possible since he did not distinguish among the various "nonprofessional" staff. Unlike Lynch and Verdin and our own findings, his results indicated that the middle group (clerical/paraprofessional staff) were more satisfied, but this was not proven to be statistically significant. He was unable to establish a strong relationship between occupational level and satisfaction. Peter F. McNally com- pared the job motivation and satisfaction of reference staff in ten Ontario public libraries, investigating the hypothesis that professional reference librarians would rank higher on both aspects than would reference technicians or other groups doing reference work. Although both groups were at a reasonably high level of satisfaction, his findings contrasted with most other studies in that the professionals were "at least as dissatisfied and unmotivated, if not more so, than other groups." 15 This dissatisfaction may have been related to the organizational environment, but further study would be needed to determine the exact causes.

Aside from the few comparative studies noted above, most of the research or literature focusing on library paraprofessionals discusses job design, task assignment, or training. A notable exception is Russell's questionnaire, mentioned before, which was sent to paraprofessional library staff in a sample of academic and public libraries in Great Britain. ${ }^{16}$ His findings of a strong dissatisfaction among paraprofessionals with their status with the scope of their duties and responsibilities, and with the opportunities for promotion, supports our results.

\section{METHODOLOGY AND LIMITATIONS}

This study, funded through a grant awarded by the Librarians Association of the University of California, was designed to compare both satisfaction and selfreported frequency of job activities across a broad spectrum of librarians and library assistants in the University of California libraries. A three-part questionnaire was designed based on the Minnesota Satisfaction Questionnaire used by S.S. Chwe in his 1976 dissertation that compared the job satisfaction of catalogers and reference librarians in academic libraries. ${ }^{17}$ A modification of his questionnaire was pretested on a random sample of five librarians and five library assistants at all nine University of California campuses, then revised, and in 1983 a total of 889 questionnaires were returned by 326 librarians and 563 library assistants. ${ }^{18}$ The response from a staff of 599 librarians and 1,573 library assistants is considered high for university question- 
naires. Sixty-three percent of the respondents were library assistants and 37 percent were librarians. Although the top three levels of administrators-university librarians, associate and assistant university librarians-were included in the mailing, their number was so small that, for reasons of confidentiality, they have been excluded from the report. The process of data gathering, analysis, and paper writing has been lengthy.

The questionnaire was organized into three parts. Part one asked respondents to assign frequency levels to a wide range of library activities. These activities were chosen either to reflect the traditional distinctions made between "professional" and "nonprofessional" responsibilities (e.g., commercial database searching versus checking out library materials), or to highlight the most hotly debated areas of overlap (e.g., providing reference assistance or performing original cataloging). To clarify the role of librarians in contrast to library assistants, we asked a series of questions regarding access to continuing education and channels of influence ranging from involvement with training and supervision to policy and budget decisions for a single department or the library as a whole. Part two of the questionnaire asked respondents about the level of satisfaction they experienced. The first question in this section asked them to rate their overall satisfaction. The remainder of the questions focused on specific aspects of the work environment. Here were placed questions about promotion criteria and staff development as well as specific satisfaction needs defined by Maslow's categories of "lower order" (physiological and social) and "higher order" (esteem and self-actualization). Part two concluded with three open-ended questions asking respondents to use their own words to describe what they liked least and most about their jobs and what they would most like to change if they were able. The final section covered the sociodemographic and job-related characteristics of the respondents.

Statistical evidence such as this relies heavily on contrasting large groups of respondents, i.e. the entire population of li- brary assistants with the entire population of librarians. Since we were especially interested in variations and similarities between lower and higher steps of staff within specific kinds of library departments, some of our data is derived from a small number of respondents and so does not prove validity under standard statistical tests. For our purposes, these responses were extremely relevant since they were indicators of what may be significant future shifts in responsibility and blurring of professional and paraprofessional roles. In order not to prejudice our response, we did not ask specific questions in the survey about the blurring of roles. Although our survey results show evidence of overlapping responsibilities, only the essay section elicited responses that directly addressed role ambiguity.

\section{We faced the problems of how to suf- ficiently describe the library tasks we included so that they could be la- belled "professional" or "parapro- fessional."}

In developing part one of the questionnaire, we faced the problem of how to describe the library tasks we included sufficiently so that they could be labelled "professional" or "paraprofessional." In fact, the difficulty we had in doing this parallels the problems faced by the profession in trying to define what it is that each class of library employee does that makes it unique and thus rewarded differentially. This problem is compounded by the tendency of respondents to over-report the importance of their own jobs. To compensate we designed task descriptions that allowed us to correlate frequency of task performance with measures of complexity or responsibility. For example, we combined the responsibility of supervision with the number and levels of employees supervised, and working at the reference desk with the frequency with which the respondent worked unsupervised or with employees of a higher level. 


\section{POPULATION GROUP AND CLASSIFICATION STRUCTURE}

The first table shows the number and percent of respondents; the second table breaks down the responses by campus.

The demographic section of our questionnaire can be summarized to show a composite portrait of the "typical" librarians and library assistants who responded. The University of California librarian is most likely to be a female in the associate rank between the ages of 30 and 39 who has a master's in librarianship and a bachelor's in another academic field. Although she has worked in the U.C. Library system from 11 to 20 years, she has only been in her present position an average of 0 to 5 years. Her primary responsibilities are in public service in a central, rather than a branch, library. She supervises library assistants and interacts with 6 to 15 fellow library employees daily. Very little of her time (15 percent) involves clerical or repetitive tasks and she spends between 1 and 4 hours per month on committee work. The composite library assistant respondent is female, but in contrast to the typical librarian, her age may range from 20 to 39 . She is at the Library Assistant II rank with a bachelor's degree and 5 years or less of U.C. Library system experience. She also works in a central library but primarily in technical services where over 80 percent of her time is spent doing clerical or repetitive production tasks. She is most likely to supervise student library employees and not to serve on committees. From this composite the reader could conclude that librarians and library assistant job responsibilities are distinctive and that there is little overlap or blurring. However, when the library assistant responses are broken down by rank, it was found that the higher ranks, LA III and IV, showed important areas of similarity to librarians.

\section{JOB RESPONSIBILITIES}

How did the duties of librarians and library assistants compare? What were the significant areas of difference and/or overlap? To answer these questions, we examined reported frequency of tasks and responsibilities in four areas of library work: collection development, technical service (bibliographic access), public service, and management.

\section{Collection Development}

Respondents were asked to identify how frequently they performed four aspects of collection development activity: bibliographic verification, selection, weeding, and consulting with faculty. Table 3 shows that those three activities that influence the content and purpose of the collection are, as we expected, more frequently done by librarians than by library assistants. But certain areas of overlapping responsibilities are also evident.

Bibliographic verification, for instance, the one activity that we hypothesized would be overwhelmingly the responsibility of library assistants, is done almost equally by both groups. It is unclear from the responses if those librarians who report doing bibliographic checking for collection development see this as a legitimate part of their job responsibilities. Perhaps they are trouble-shooting difficult orders already attempted by library assistants. This table also shows that 10 to 11 percent of library assistants frequently engage in building collections. However, a closer examination of the responses indicates that approximately 80 percent derive

TABLE 1

NUMBER AND PERCENT OF RESPONDENTS BY PERSONNEL TITLE AND RANK

\begin{tabular}{lrllrr}
\hline \hline & No. & $\%$ & & No. & $\%$ \\
\hline Library Assistant I & 88 & 16 & Assistant Librarian & 40 & 12 \\
Library Assistant II & 207 & 37 & Associate Librarian & 159 & 47 \\
Library Assistant III & 172 & 31 & Librarian & 123 & 36 \\
Library Assistant IV & $\underline{96}$ & $\underline{17}$ & University Librarian & $\underline{16}$ & $\frac{5}{338}$ \\
$\quad$ Totals & 563 & $101^{*}$ & & 100 \\
\hline
\end{tabular}

*In this table, as well as subsequent ones, percentages sometimes total to more or less than 100 because of rounding. 
from library assistants at the step III or IV levels (see table 4).

For example, of the forty-four library assistants who select materials to acquire "fairly often or very frequently," thirtyfive are library assistant IIIs and IVs. While this is a relatively small number, it does raise some interesting questions: Are these library assistants with esoteric languages or located in small libraries, or has a decision been made by their library administrators permanently to reassign a traditionally professional task?

\section{Technical Services}

Job responsibilities in technical service areas have been shifting for some time in libraries. When respondents were asked

TABLE 2

PERCENTAGE OF RESPONDENTS BY STATUS AND CAMPUS

\begin{tabular}{lcc}
\hline \hline Campus & $\begin{array}{c}\% \\
\text { Librarians }\end{array}$ & Library Assistants \\
\hline Berkeley & 25 & 30 \\
Davis & 12 & 16 \\
Irvine & 6 & 7 \\
Los Angeles & 26 & 17 \\
Riverside & 4 & 5 \\
San Diego & 7 & 10 \\
San Francisco & 4 & 3 \\
Santa Barbara & 9 & 7 \\
Santa Cruz & 7 & 6 \\
\hline
\end{tabular}

how frequently they performed five tasks involving bibliographic access and control, it was clear that even those activities we hypothesized were professional-level tasks-original cataloging and name authority control-have become the responsibility of both groups (see table 5). This blurring becomes even more apparent when the responses are broken down by levels within each group as shown by table 6 .

While blurring of job duties in collection development could be seen as an anomaly, we see from table 6 that original cataloging and authority control is done with almost equal frequency by library assistants III and IV and assistant and associate librarians.

\section{Public Service}

A third area of job responsibility investigated was the public service done by librarians and library assistants. Sixty-five percent of librarians compared with 48 percent of library assistants report public service as at least one of their primary responsibilities. We identified six public service tasks, including professional and paraprofessional activities, and then asked respondents to indicate how frequently they performed these. Table 7 below shows these responses for all steps within both groups.

\section{TABLE 3}

FREQUENCY OF TASKS IN SUPPORT OF COLLECTION DEVELOPMENT

\begin{tabular}{|c|c|c|}
\hline "Fairly often" an & $\begin{array}{l}\text { es Combined } \\
\% \\
\text { LAs }\end{array}$ & $\begin{array}{c}\% \\
\text { Librarians }\end{array}$ \\
\hline \multicolumn{3}{|l|}{ Develop the collection by: } \\
\hline bibliographic verification of materials & 35 & 32 \\
\hline selecting materials to acquire & 11 & 56 \\
\hline evaluating and weeding & 11 & 43 \\
\hline conferring with faculty & 10 & 32 \\
\hline
\end{tabular}

TABLE 4

FREQUENCY OF TASKS IN SUPPORT OF COLLECTION DEVELOPMENT AT THE LIBRARY ASSISTANT LEVELS

\begin{tabular}{|c|c|c|c|c|}
\hline Com & $\begin{array}{c}\mathrm{s} \text { of " } \mathrm{F} \\
\% \\
\text { LAI } \\
\end{array}$ & $\begin{array}{c}\text { 'Very } \\
\% \\
\text { LAII } \\
\end{array}$ & $\begin{array}{c}\% \\
\text { LAIII } \\
\end{array}$ & $\begin{array}{c}\% \\
\text { LAIV } \\
\end{array}$ \\
\hline Selecting materials to acquire & 1 & 8 & 17 & 18 \\
\hline Evaluating and weeding & 3 & 8 & 17 & 14 \\
\hline Conferring with faculty & 2 & 9 & 12 & 16 \\
\hline
\end{tabular}


This table shows some interesting relationships. Clearly, handling materials is more frequently done by library assistants, and teaching library use is dramatically the purview of librarians. Information and directional assistance cuts across all lines. The responses to activity "c: answering complex reference questions" highlight the lack of precision that Veaner lamented in his article-what is perceived

\section{TABLE 5}

FREQUENCY OF TASKS

INVOLVED IN BIBLIOGRAPHIC ACCESS AND CONTROL

\begin{tabular}{|c|c|c|}
\hline "Fairly often" and "Very frequently" & $\begin{array}{c}\text { ponses } \\
\% \\
\text { LAs }\end{array}$ & $\begin{array}{c}\text { Combined } \\
\% \\
\text { Librarians }\end{array}$ \\
\hline \multicolumn{3}{|l|}{$\begin{array}{l}\text { Create bibliographic access by: } \\
\text { preparing records for }\end{array}$} \\
\hline computer input & 38 & 26 \\
\hline $\begin{array}{l}\text { assigning classification } \\
\text { numbers }\end{array}$ & 20 & 25 \\
\hline doing copy cataloging & 25 & 10 \\
\hline doing original cataloging & 14 & 28 \\
\hline control & 21 & 25 \\
\hline
\end{tabular}

as complex by one individual may be routine to another. In total, $66 \%$ of the librarians, but also $26 \%$ of the library assistants report answering complex reference questions. In an attempt to clarify "complex," we asked another set of questions that focused on whether librarians and library assistants were responsible for working on a reference desk alone-hypothesizing that in such circumstances complex questions would be routinely encountered. Library assistants responding to this question indicated that $60 \%$ do work alone fairly often or very frequently. It is interesting to speculate whether this is the beginning of a change similar to the shifts in technical services responsibilities documented above. A hierarchical division of increasing responsibility is more evident in public than technical service, with more clearly visible functions that are reserved for librarians only.

\section{Management and Supervision}

Several areas of library management were identified and studied including ad-

TABLE 6

ORIGINAL CATALOGING ACTIVITY BY STATUS AND LEVEL

\begin{tabular}{|c|c|c|c|c|c|c|c|}
\hline & $\begin{array}{c}\text { Combined Resp } \\
\% \\
\text { LAI } \\
\end{array}$ & $\begin{array}{l}\text { ses of " } \\
\% " \\
\text { LAII }\end{array}$ & $\begin{array}{l}\text { yy often' } \\
\% \\
\text { LAIII } \\
\end{array}$ & $\begin{array}{c}\text { d"Very } \\
\% \\
\text { LAIV }\end{array}$ & $\begin{array}{l}\text { uently" } \\
\text { Asst. Lbn. }\end{array}$ & $\begin{array}{c}\% \\
\text { Assoc. Lbn. }\end{array}$ & $\begin{array}{r}\% \\
\text { Lbn. }\end{array}$ \\
\hline \multirow{2}{*}{$\begin{array}{l}\text { Develop the collection by } \\
\text { doing original cataloging } \\
\text { Establishing name authority } \\
\text { control }\end{array}$} & 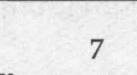 & 6 & 21 & 21 & 37 & 36 & 19 \\
\hline & 5 & 13 & 33 & 22 & 22 & 33 & 18 \\
\hline
\end{tabular}

TABLE 7

PUBLIC SERVICE ACTIVITIES OF LIBRARIANS AND LIBRARY ASSISTANTS

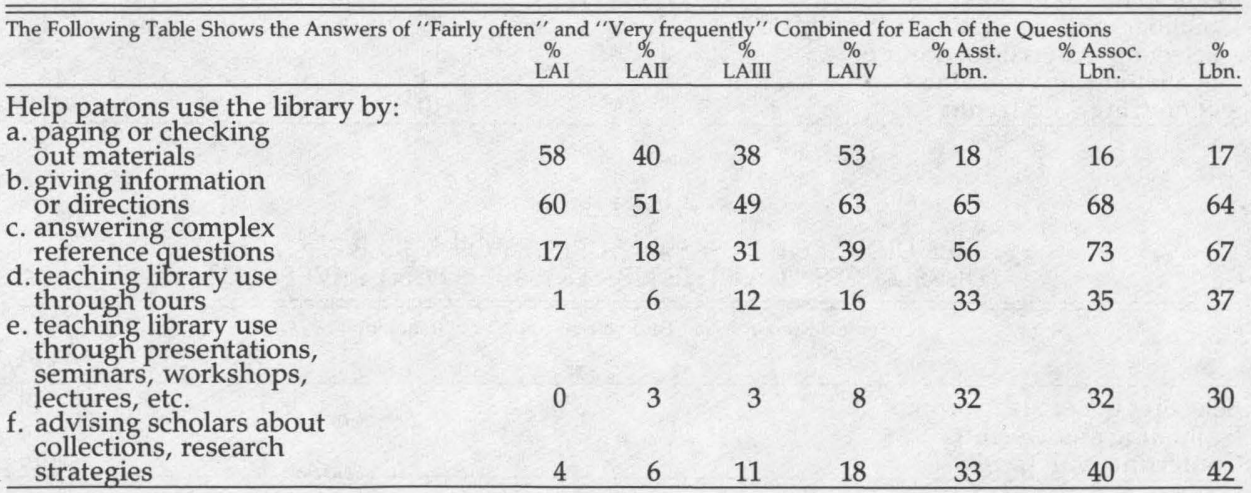


ministration, supervision, decisionmaking and perceived influence, staff training, and report-writing. Administration is more often done by librarians than by library assistants. Thirty-one percent of the librarians report administration as a primary job responsibility. For $7 \%$ of the librarians, it is their sole activity, and for an additional $24 \%$ it is a primary part of their jobs. In contrast, only $8 \%$ of library assistants report administration as a primary job responsibility.

\section{Supervision and Training}

Both librarians and library assistants report a high amount of supervisory responsibility, as reflected by table 8 .

Although supervision is done by both librarians and library assistants table 9 shows that library assistants are more involved in the direct supervision of student employees than are librarians, whereas librarians are more involved in supervising library assistants.

Not surprisingly, responsibility for training follows a similar pattern. Fortysix percent of library assistants, but only $10 \%$ of librarians, fairly often or very frequently train student library employees. Library assistants also more often report training clerical employees. Librarians, as might be expected, more often report spending time training other librarians: $15 \%$ do so fairly often or very frequently and only $34 \%$ never train their colleagues. However, an interesting exception to the parallel between supervision and training is found in the case of library assistants. Whereas $62 \%$ of the librarians report being responsible for the direct supervision of library assistants, only $19 \%$ report that they fairly often or very frequently spend time training library assistants. By contrast, although a much smaller percentage (34\%) of the library assistants report having direct supervision of other library assistants, a higher percentage $(24 \%)$ report that they fairly often or very frequently spend time training their library assistant colleagues. While there is no way of knowing from these data what percent of library assistants-at what levels-require training, there is an interesting difference in the amount of training time library assistants receive based on whose supervision they are under.

\section{Participatory Management}

The questionnaire responses show that whether or not librarians classify themselves as administrators or supervisors, they are much more involved in participatory management activities that allow them to influence library policies, goals, and objectives. Committee work is the near-exclusive domain of librarians. Only $8 \%$ of librarians compared to fully $65 \%$ of the library assistants report spending no time on committee work. Furthermore, among those who report time spent on committees, the extent of time is far greater for librarians.

TABLE 8

SUPERVISORY RESPONSIBILITIES OF LIBRARIANS AND LIBRARY ASSISTANTS

\begin{tabular}{lccccc}
\hline \hline Supervise & Lbns & LAS & SLES & Clerical & Other \\
\hline $1-20+$ & & & & & \\
Lbns & 41 & 62 & 41 & 22 & 14 \\
LAs & 1 & 34 & 59 & 9 & 3 \\
\hline
\end{tabular}

TABLE 9

CATEGORIES OF EMPLOYEES SUPERVISED

\begin{tabular}{lllr}
\hline \hline & \multicolumn{2}{c}{ \% Who Supervise None } & \multicolumn{2}{c}{ \% Who Supervise 1-20+ } \\
& Ls & LAs & LAs \\
\hline Student library employee & 59 & 41 & 41 \\
Clerical workers & 78 & 91 & 22 \\
Other & 86 & 97 \\
Library assistants & 38 & 97 & 14 \\
Librarians & 59 & 66 & 62 \\
\hline
\end{tabular}


As has been shown, librarians are more heavily involved in the management of academic libraries-in administration, in supervision of higher-level employees, and in committee work. They are also more involved than library assistants in direct and indirect activities that provide an opportunity to gain information and wield influence. As can be seen in table 10, librarians report closer working relationships with colleagues and more frequent attendance at conferences, workshops, and continuing education programs than do library assistants.

This higher level of contact, collaboration, and continuing education experienced by librarians translates into a greater amount of influence on management decision-making activities, such as analyzing, planning, evaluating, and developing. Table 11 compares the decisionmaking activities and perceptions of librarians and library assistants.

Not only do librarians have more decision-making responsibilities than library assistants, but the collaborative and continually changing nature of librarians' jobs allow access to information and channels of influence not available to library assistants.

\section{Writing Tasks}

Involvement in job-related writing tasks is very heavily the responsibility of librarians. Although the writing done by each group is most often of letters and memos, $71 \%$ of the librarians compared with $46 \%$ of the library assistants report this activity on a fairly often or very frequent basis. In the next most frequent writing activityevaluations, reports and proposals-the gap between librarians and library assistants remains at $25 \%$. One half of librarians and almost one quarter of library assistants engage in this fairly often or very frequently. Even the writing of procedures, manuals and handbooksmaterials more often used by technical

TABLE 10

FREQUENCY OF INTERACTIVE ACTIVITIES OF LIBRARIANS AND LIBRARY ASSISTANTS IN PERCENTS

\begin{tabular}{|c|c|c|}
\hline "Fairly often" and & $\begin{array}{l}\text { S Combined } \\
\% \\
\text { LAs }\end{array}$ & $\begin{array}{c}\% \\
\text { Librarians } \\
\end{array}$ \\
\hline Work collaboratively with others & 64 & 81 \\
\hline \multirow{2}{*}{\multicolumn{3}{|c|}{ Have contact with staff beyond my }} \\
\hline & 58 & 75 \\
\hline Must learn new methods or technologies & 36 & 53 \\
\hline Attend workshops & 9 & 49 \\
\hline
\end{tabular}

TABLE 11

FREQUENCY OF DECISION-MAKING ACTIVITIES OF LIBRARIANS AND LIBRARY ASSISTANTS IN PERCENTS

\begin{tabular}{|c|c|c|}
\hline "Fairly & $\begin{array}{l}\text { Combined } \\
\% \\
\text { LAs }\end{array}$ & $\begin{array}{c}\% \\
\text { Librarians }\end{array}$ \\
\hline $\begin{array}{l}\text { Analyze and evaluate programs, } \\
\text { policies and services }\end{array}$ & 17 & 46 \\
\hline & & \\
\hline work unit or department & 27 & 51 \\
\hline $\begin{array}{l}\text { Plan or develop new procedures } \\
\text { or services for my library or }\end{array}$ & & \\
\hline $\begin{array}{l}\text { library system } \\
\text { Am able to influence important }\end{array}$ & 7 & 24 \\
\hline $\begin{array}{l}\text { Am able to influence important } \\
\text { decisions in my department }\end{array}$ & 24 & 58 \\
\hline $\begin{array}{l}\text { Am able to influence important } \\
\text { decisions in the library }\end{array}$ & 15 & 26 \\
\hline Make policy decisions & 7 & 48 \\
\hline
\end{tabular}


services staff-is done more frequently by librarians (35\%) than by library assistants $(23 \%)$. Paralleling the teaching role of librarians, the writing of instructional library materials is almost completely done by librarians. Twenty-one percent of librarians write instructional materials fairly often or very frequently and only $26 \%$ never do so. In contrast, only $6 \%$ of the library assistants write instructional materials with any real frequency and $72 \%$ report that they never do so.

\section{Blurring or Overlapping}

In examining self-reported frequency of job tasks and responsibilities, our study has found a major overlap of responsibilities in the area of creating bibliographic access, small but provocative overlaps in the areas of collection development and public services, and a strong division of responsibilities in management-related activities. In many cases in which the overlap occurred, the duties and responsibilities of library assistants at the III and IV levels were blurring into those of librarians. The heaviest blurring occurred in the frequencies reported for certain tasks by library assistant IV and assistant librarian, such as for original cataloging. If Veaner's hypothesis is correct, these two groups of library assistants should be the most dissatisfied since their roles are the most ambiguous. How satisfied are librarians and library assistants within the University of California system? Can this dissatisfaction be linked to role ambiguity or to specific employment conditions?

\section{JOB SATISFACTION}

As a group, University of California library staff are extremely satisfied with the work they do-reporting higher levels of job satisfaction than many other American workers. However, a comparison of the satisfaction levels reported by librarians and library assistants shows a significant difference between the two groups.

Library assistants and librarians were asked three questions relating to their overall job satisfaction. Asked "In general how satisfied are you with your present job?" $76 \%$ of the librarians, but only $50 \%$ of the library assistants, selected the two highest categories of satisfaction on a 5point scale. Also, when asked how satisfied they are with the nature of the work they do, $82 \%$ of the librarians but only $52 \%$ of the library assistants checked the two highest satisfaction ratings. Furthermore, although $44 \%$ of the librarians gave the "nature of their work" the highest possible rating (a \#5), only $22 \%$ of the library assistants did so. A third question, included in the section on job description, asked the respondents how frequently they "do the kind of work they enjoy." Response categories for this item ranged from never, seldom, sometimes, and fairly often to very frequently. Whereas $45 \%$ of the librarians indicated that they very frequently do the kind of work they enjoy and another $42 \%$ said that they fairly often do, only $19 \%$ of the library assistants gave the very frequently response and another $39 \%$ indicated that this happened fairly often. Combining the two categories of frequency, fully $87 \%$ of the librarians indicate that they at least fairly often do the kind of work they enjoy: this compares with 59\% of library assistants. The most significant result of our survey and, to us, the most surprising, was the high satisfaction level of the librarians. Table 12 compares the job satisfaction reported by librarians and library assistants.

\section{Fully 87 percent of librarians indicate that they at least fairly often do the kind of work they enjoy: this com- pares with 59 percent of library assis- tants.}

This discrepancy between the two groups prompted us to investigate what areas show the most job dissatisfaction, and to ask if these differ for librarians and library assistants. The dissatisfaction of both groups is markedly clustered in certain steps and ranges within the salary/ promotion hierarchy. However, some dissonant themes cut across all levels within each group.

We found that one of the most significant ways the two groups differ is in their 
assessment of how effectively the library is using their expertise and abilities. On two questions that asked how well respondents felt their education and training were being used, $70 \%$ or more of the librarians answered in the highest two satisfaction categories compared to $30 \%$ or less of the library assistants. The ability to help the public was valued very highly by public and technical service librarians alike. In the essay section one librarian wrote that "faculty contact" and being engaged in "ongoing university research through my liaison assignments" was the most rewarding part of the job.

Another traditional area of dissatisfaction in organizations focuses on salary and promotion issues, and the library environment is no exception. Both librarians and library assistants reported a significant amount of dissatisfaction with salary and advancement. However, the difference in responses was much wider in this area than in any other. Eighty percent or more of the library assistants reported dissatisfaction with this part of their jobs. Table 13 summarizes these areas of dissatisfaction and shows the wide discrepancy in responses between the two groups.

As noted before, when the responses to the job satisfaction questions were broken down by ranks within the librarian and li- brary assistant series, there are markedly different satisfaction levels. The widest gap in response occurred between library assistants I and II and library assistants III and IV.

The clumping of dissatisfaction around certain issues, and the division of response, especially between the two lowerlevels of library assistants and the two upper-levels can be characterized as focusing on issues of equity and just reward. Our assumption in designing the original questionnaire was that major sources of complaint for librarians would be the amount of "clerical" or paraprofessional work they had to perform, and that library assistants would object to monotonous and repetitive work. However, neither was the case. Pockets of dissatisfaction rather appeared at certain crucial steps within the library assistant rank around promotion opportunities, promotion criteria and procedures, as well as over the broad satisfaction question discussed above. In each case there was both a strong discrepancy between librarians and library assistants, and between the highest level (IVs) library assistants and the lower steps (most noticeably the LA IIIs). This same discrepancy was noticed within the librarian ranks, but it was less pronounced.

TABLE 12

OVERALL JOB SATISFACTION OF LIBRARIANS AND LIBRARY ASSISTANTS IN PERCENTS

\begin{tabular}{|c|c|c|c|c|c|}
\hline $\begin{array}{l}\text { In general, how satisfied } \\
\text { are you with your present } \\
\text { job: }\end{array}$ & $\begin{array}{l}\text { Not at all } \\
\text { satisfied } \\
\text { (1) }\end{array}$ & (2) & $\begin{array}{l}\text { Somewhat } \\
\text { satisfied } \\
\text { (3) }\end{array}$ & (4) & $\begin{array}{l}\text { Very } \\
\text { satisfied } \\
(5)\end{array}$ \\
\hline $\begin{array}{l}\text { Librarians } \\
\text { Library Assistants } \\
\text { How satisfied are you with } \\
\text { the nature of the work } \\
\text { you do: }\end{array}$ & $\begin{array}{l}2 \\
6\end{array}$ & $\begin{array}{r}5 \\
12\end{array}$ & $\begin{array}{l}18 \\
32\end{array}$ & $\begin{array}{l}44 \\
30\end{array}$ & $\begin{array}{l}31 \\
20\end{array}$ \\
\hline $\begin{array}{l}\text { Librarians } \\
\text { Library Assistants }\end{array}$ & $\begin{array}{l}1 \\
5\end{array}$ & $\begin{array}{r}2 \\
12\end{array}$ & $\begin{array}{l}14 \\
31\end{array}$ & $\begin{array}{l}38 \\
30\end{array}$ & $\begin{array}{l}44 \\
22\end{array}$ \\
\hline $\begin{array}{l}\text { On my present job, I do the } \\
\text { kind of work I enjoy: }\end{array}$ & $\begin{array}{l}\text { Never } \\
(1)\end{array}$ & $\begin{array}{l}\text { Seldom } \\
\text { (2) }\end{array}$ & $\begin{array}{l}\text { Sometimes } \\
\text { (3) }\end{array}$ & $\begin{array}{l}\text { Fairly } \\
\text { often } \\
(4)\end{array}$ & $\begin{array}{l}\text { Very } \\
\text { frequently } \\
\text { (5) }\end{array}$ \\
\hline $\begin{array}{l}\text { Librarians } \\
\text { Library Assistants }\end{array}$ & $\begin{array}{l}0 \\
3 \\
\end{array}$ & $\begin{array}{r}1 \\
10 \\
\end{array}$ & $\begin{array}{l}12 \\
28 \\
\end{array}$ & $\begin{array}{l}42 \\
39 \\
\end{array}$ & $\begin{array}{l}45 \\
19 \\
\end{array}$ \\
\hline
\end{tabular}


TABLE 13

SOME ASPECTS OF JOB SATISFACTION SHOWING THE GREATEST DISCREPANCY IN PERCENTS

\begin{tabular}{lcc}
\hline \hline \multicolumn{1}{c}{ Two Highest Satisfaction Ratings (" 4 " and " 5 ") $\begin{array}{c}\text { Combined } \\
\% \\
\text { LAs }\end{array}$} & $\begin{array}{c}\% \\
\text { Librarians }\end{array}$ \\
\hline $\begin{array}{l}\text { Work you do in relation to your } \\
\text { education and training }\end{array}$ & 27 & 70 \\
$\begin{array}{l}\text { Opportunities to use your education } \\
\text { and training }\end{array}$ & 30 & 73 \\
$\begin{array}{l}\text { Opportunities for your own advancement } \\
\text { Salary you receive compared with that } \\
\text { of others doing a comparable job }\end{array}$ & 16 & 47 \\
$\begin{array}{l}\text { Opportunities you have to change } \\
\text { your job }\end{array}$ & 28 & 58 \\
$\begin{array}{l}\text { Criteria used in advancement } \\
\text { Procedures used in advancement }\end{array}$ & 23 & 48 \\
\hline
\end{tabular}

Interestingly, salaries and promotions are viewed with greater dissatisfaction than the relationship to supervisors. This may be due to the fact that within the university and library structure, supervisors have significantly less control over the salary/promotion opportunities of their employees. Merit increases for eligible librarians and library assistants are rather fixed. Direct supervisory control over librarians' merit/promotion decisions is buffered by other administrative input and a strong system of peer review with mutually established criteria for assessing performance and determining parity. Compared to librarians, a library supervisor can have a greater effect on a library assistants' salary and promotion opportunities, yet even this influence is circumscribed by the library assistants' classification structure. Library assistant ranks I-IV are based on the job responsibilities of the position, not the skills and abilities of the person hired. Performance is rewarded within a rigid structure of steps that reach a final plateau for each rank. Many long-term library assistants have "topped-out" and are no longer eligible for merit raises. Movement from rank to rank, promotion, for library assistants is not based on the supervisor's assessment nor on the employee's job performance but on job duties of the position. We have observed some of the consequences of these differences in salary structure, performance expectations, and rewards in the job description section of this paper.
Librarians, on the other hand, do not have a formal job description. They are expected to show a high degree of initiative, professional and personal commitment to developing and contributing to the mission of the library and the profession. Librarians unwilling to make this commitment remain indefinitely at a lower rank. However, no matter what their primary job responsibilities or descriptions, those librarians who choose to contribute will continue, for a much longer period than library assistants, to be rewarded with salary increases and promotions recognizing those contributions.

\section{CONCLUSION}

We decided to examine the rewards and responsibilities of librarians and library assistants at the University of California in order to test a thesis by Allan Veaner. He asserts that because librarians and library assistants often perform tasks demanding the same expertise as librarians, library assistants tend to feel resentful. Our study has found that their dissatisfactions stem not only from inequity in pay, but also in promotion procedures, job development, and general status. Blurring of responsibilities is an important issue in a hierarchical organization, particularly as such blurring causes dissatisfaction in an environment that is as service-oriented and people-dependent as a library.

We found that while there are a number of areas where both professionals and paraprofessionals appear to perform the 
same work, when the frequency of that work and the span of control or responsibility are examined, there are often clear distinctions between the two groups. However, we did uncover some provocative areas of blurring where tasks traditionally regarded as professional were being performed by library assistants.

These blurred areas may well point to a general shifting of certain tasks from professional to paraprofessional levels of responsibility. Reassignment of responsibilities from professional to support staff has characterized library work for decades. Nowadays librarians can list many responsibilities that were always done by librarians and are now routinely done by support staff. This trend is likely to continue, and perhaps even accelerate as libraries deal with budget constraints and as the profession meets the demands and challenges of new information needs and constantly changing technology. However, even if many tasks were not being done simultaneously by both groups, a work situation marked by shifting responsibilities may cause misunderstanding of roles and of appropriate rewards.

And in fact this seems to be the case. Although each group's satisfaction rate is very high, a comparison of the satisfaction levels shows a wide gap between librarians and library assistants, with the highest discrepancies in the areas of worker utilization and salaries. As a group, U.C. library assistants are seriously dissatisfied with the reward structure and perceive that they are being treated inequitably.

This juxtaposition of high general satisfaction rate with strong dissatisfaction with parts of the job is reflected in the responses library assistants wrote in the comment section. Written in response to the question, "What do you like least about your job?", the following statement illustrates the sense of injustice that was expressed by many:

I would change the pay-scale so that I was paid according to my skills as I learned them; that is the built-in step raises are so far apart that one has to work twenty years to get to the top of the pay scale. After one gets to the top, there is nowhere else to go, especially if one is doing professional work but not being paid professional wages, as are librarians. . . Sorry if this seems like more than one aspect, but it really is one important problem, especially in determining career satisfaction and human dignity.

Interestingly, this person marked the next highest column of the satisfaction scale in response to the question "In general how satisfied are you with your present job?" and likewise when asked to rate his satisfaction with the nature of the work he was doing. Procedures and opportunities for advancement were given the lowest marks.

After looking at a series of similar complaints and comparing the low satisfaction areas of promotion and compensation to the high satisfaction with intrinsic rewards such as autonomy and variety, we could speculate that paradoxically what contributes to higher satisfaction in one area may lead to disappointment in another. A more challenging line of duties will make the work more interesting, but it will also invite unfavorable comparison with librarians who seem to be involved with similar or equally difficult assignments that offer them substantially better rewards. It is very easy to conclude that two interactive but unequal work and reward systems, one at a higher level than the other, will inevitably lead to conflict and dissatisfaction. However, if workers are not seeing their roles clearly, and if tasks are constantly shifting between librarians and library assistants causing dissatisfaction, there may be some solid ways for management to clarify roles and to establish equity. Processes both of action and communication are needed to affect staff perceptions. Library administrators should carefully examine library tasks to ensure that they are being done by the most appropriate personnel and rewarded at an appropriate level.

Since 1977 when a fourth step was added to the initial three, the University of California library administration has been concerned with restructuring the library assistant series to compensate those employees for their increasing supervisory responsibilities and special subject or management expertise. A fifth step was under consideration, but not yet implemented while our survey was conducted. 
Nevertheless our findings make it doubtful that this additional step (effective since April 1983) will solve the endemic problems mentioned by library assistants in our report. Unlike the lower ranks of the assistant series, the library assistant $\mathrm{V}$ category is part of the Administrative and Professional Staff series that was established to recognize "unique and valuable contributions to the University's overall mission of education, research, and public service and to encourage individual achievement, professionalism, initiative, and creativity." Job descriptions resemble that of academic librarians: "advanced paraprofessional knowledge enabling the performance of a full range of coordinating and/or highly specialized functional/subject-area activities (i.e. reference service at a level comparable to professional librarians, full original cataloging without routine revision). ${ }^{\prime 19}$ Its pay scale is open-ended and based on comparative merit. $^{20}$

If role blurring is a problem now, this deliberate overlap, although reflected in salary and status will not permit access to peer review and other important characteristics that distinguish academic librarians from their paraprofessional colleagues. If appropriately funded and administered, the new open merit system could, if applied to ranks I-IV, address the inequity in pay and status currently experienced by library assistants who assume new responsibilities or contribute to the library's mission in significant ways without a major change.

However, because the University of California libraries experience a varying level of funding in the state each year, they cannot always offer appropriate monetary rewards for employee performance-a condition shared by many other public and academic libraries. The new group of library assistant Vs are already experiencing problems in equity and monetary rewards.

The survey respondents wrote about other kinds of recognition in addition to pay. While mentioning the need for monetary rewards, many of the library assistants also emphasized a need for appreciation. One respondent identified the two major aspects of the job that he wished to change as "getting a salary increase commensurate with my responsibilities" and changing the "apparent low prestige and incomprehension in which my area of work seems to be held by many librarians on campus." This comment reflects Russell's finding that "Many nonprofessional Library staff do not want to become professional librarians, but they do want a fulfilling job and one that offers some opportunity for promotion. "'21 A key word here is fulfilling.

There are other ways libraries can validate their employees' work but much perceivable good faith must go into the effort otherwise it will be construed as manipulative. As our survey has shown, library assistants are fairly restricted in their access to committee work and in their collegial relationships within the library. Perhaps more involvement by library assistants in participatory management activities would help them gain a sense of control and influence and allow them to communicate to professional librarians the importance and dignity of the work they do.

Librarians also need to take a more aggressive role, as Veaner has called for, in communicating to library assistants the very real difference in job content, span of control and responsibility, peer review, and performance expectations between librarians and library assistants. Many library assistants have very little idea of the true nature of librarians' work or of the open-ended nature of the performance expectations they must meet for promotion.

\section{Another traditional area of dissatis- faction in organizations focuses on salary and promotion issues and the library environment is no exception.}

Further research is needed to ascertain the extent to which the obviously perceived inequity by library assistants injures their work performance or their relationships with professional librarians. Our study shows that in general, the work 
environment of the University of California libraries provides a climate that contributes to the meaningfulness of work. The greatest agreement between librarians and library assistants was found in their satisfaction with such aspects of their work as the opportunity to be of help to others, good relationships with co- workers, job security, variety, flexibility, and a surprising degree of autonomy. However, the responses also show that even workers who are in an intrinsically satisfying environment become critical and less satisfied if they perceive that they are not being treated fairly.

\section{REFERENCES AND NOTES}

1. Betty Hartzell, "Publisher's Letter: Job Satisfaction Is Number One" Personnel Journal 67:6 (Mar. 1988).

2. "Satisfaction Top Job Concern," San Francisco Examiner (Jan. 31, 1988).

3. Michael M. Gruneberg, Understanding Job Satisfaction (London: Macmillan, 1979), p.142.

4. Philip H. Mirvis and Edward J. Hackett, "Work and Work Force Characteristics in the Nonprofit Sector," Monthly Labor Review 106:3-12 (April 1983).

5. Allen B. Veaner, "Continuity or Discontinuity-a Persistent Personnel Issue in Academic Librarianship," Advances in Library Administration \& Organization 1:1-20 (1982).

6. Ibid., p.3.

7. Norman J. Russell, "Professional and Non-Professional in Libraries: The Need for a New Relationship," Journal of Librarianship 17:293-310 (Oct. 1985).

8. Ibid., p.303.

9. Jeffery H. Greenhaus, Claudene Seidel, and Michael Marinis, "The Impact of Expectations and Values on Job Attitudes" Organizational Behavior and Human Performance 31:394-417 (June 1983); Charles A. O'Reilly III, G. Nicholas Parlette, and Joan R. Bloom, "Perceptual Measures of Task Characteristics: The Biasing Effects of Differing Frames of Reference and Job Attitudes," Academy of Management Journal 23:118-31 (Mar. 1980); and Cynthia D. Fisher, "On the Dubious Wisdom of Expecting Job Satisfaction to Correlate with Performance," Academy of Management Review 5:507-612 (Oct. 1980).

10. James L. Bowditch and Anthony F. Buono, Quality of Work Life Assessment: A Survey-Based Approach (Boston, Mass.: Auburn House, 1982), p.2, 3, 19.

11. Beverly P. Lynch and Jo Ann Verdin, "Job Satisfaction in Libraries: Relationships of the Work Itself, Age, Sex, Occupational Group, Tenure, Supervisory Level, Career Commitment, and Library Department," Library Quarterly 53:434-47 (Oct. 1983).

12. Kenneth H. Plate and Elizabeth W. Stone, "Factors Affecting Librarian's Job Satisfaction," A Reader in Library Management, Ross Shimmon, ed. (London: Clive Bingley, 1976), p.146-60. Susanne P. Wahba, "Motivation, Performance and Job Satisfaction of Librarians," Law Library Journal 71:270-78 (May 1978).

13. William J. Vaughn and J.D. Dunn, "A Study of Job Satisfaction in Six University Libraries," College \& Research Libraries 35:163-77 (May 1974).

14. Lawrence D. Prybil, "Job Satisfaction in Relation to Job Performance and Occupational Level," Personnel Journal 54:94-100 (Feb. 1973).

15. Peter F. McNally, "Job Motivation and Satisfaction of Reference Staff in Public Libraries," Argus 11:15 (Jan.-Feb. 1982).

16. Russell, "Professional and Non-Professional in Libraries," p.301-303.

17. S. S. Chwe, "A Comparative Study of Librarian's Job Satisfaction: Catalogers and Reference Librarians in University Libraries," Journal of Academic Librarianship 4:139-43 (July 1978).

18. Address labels were provided for the librarians from the secretary of each campus's Librarian's Association of the University of California (LAUC). For library assistants, a mailing list was obtained from the U. C. system-wide personnel office.

19. University of California. "Class Specifications-B.15 Series Concept," Staff Personnel Manual (April 1983) p.2.

20. Currently each rank of library assistant is attached to a specific job. Therefore, to be promoted from LAI to LAII, one must change jobs. This system is a present source of major dissatisfaction.

21. Russell, "Professional and Non-Professional in Libraries," p.299. 